\title{
ANTICIPATED STRATEGY TO REDUCE INFORMAL ENTREPRENEURIAL CULTURE: INSIGHTS FROM PAKISTAN
} Aamar Ilyas $^{1 *}$, Muhammad Ali $^{2}$, Ahmed Hussain Khan ${ }^{3}$, Shahid Saleem ${ }^{4}$, Hafiz Muhammad Imran Akram ${ }^{5}$ ${ }^{1 *}$ University of Central Punjab, Gujranwala Campus, Pakistan; ${ }^{2}$ Institute of Business Administration, University of the Punjab, Lahore, Pakistan; ${ }^{3}$ National College of Business Administration \& Economics, Lahore, Pakistan; ${ }^{4}$ University of Central Punjab, Gujranwala Campus, Pakistan; ${ }^{5}$ Assistant Professor, University of the Punjab, Gujranwala Campus, Pakistan.

Email: ${ }^{1 *}$ aamarilyas@gmail.com, ${ }^{2}$ mali@ibapu.edu.pk, ${ }^{3}$ msesme@gmail.com, ${ }^{4}$ principal.gujranwala@ ucp.edu.pk Article History: Received on $23^{\text {rd }}$ May 2021, Revised on $30^{\text {th }}$ May 2021, Published on $4^{\text {th }}$ June 2021

\section{Abstract}

Purpose of the study: The policy tactics concerning minimizing informal entrepreneurship have been dominant in developed nations but with fewer developing nations. Which policy approach(s) is (are) best entrepreneurs to eradicate or minimize the informal entrepreneurial practices in the eyes of informal?

Methodology: The target population had comprised of micro and small firms from two sectors: retail and manufacturing. The unit of analysis is the individual. Respondents are informal entrepreneurs who are working in the Gujranwala district. Finally, a sample size of 30 has been used in this study. Fifteen respondents were selected from each sector. Evaluate the thematic analysis is a better fit for this study, and interpretive phenomenological analysis is unsuitable. The researcher of this thesis has transferred thirty transcripts into qualitative software NVivo 10 when thirty interviews had been transcribed.

Main Findings: Finally, this study concludes that sectoral variations like informal work identified by various international studies would not suit one universal policy approach. The landscape of informal entrepreneurship is not homogenous in Pakistan. This study would have proposed that a cross-sectoral comparison will be conducted in the future in Pakistan. Furthermore, researchers can explore the causes of lack of trust in government and barriers to face policy implication in future studies.

Applications of this study: The findings of this research are essential for practical implication as well as theoretical knowledge. This study will be helpful for Pakistani government institutes/departments at the federal, provincial, district, and town levels to minimize the informality culture.

Novelty/Originality of this study: It could predominantly contribute to knowledge on reducing the informality culture. Some factors have not been explored before this study.

Keywords: Informal Entrepreneurial Culture, Deterrence Option, Incentives, Persuasion: Indirect Control, Pakistan.

\section{INTRODUCTION}

A substantial number of informal activities are taking place in both developed (Williams, 2014) and developing countries (Mughal, \& Schneider, 2018; Bennett, 2010, Ilyas et al.,2020), which does not appear in official statistics. However, this biased portrayal of the informal economy as a negative and diminishing sector has come under criticism (Neuwirth, 2011; Günther \& Launov, 2012; Al-Mataani et al., 2017; Webb et al., 2013). First and foremost, the globalization theory is increasingly gaining momentum among economists and other scholars (Webb et al., 2014: Williams \& Nadin, 2010; Suhaimi et al., 2016; Thai \& Turkina, 2013). Deconstructing the arguments of the decreasing thesis, the globalization thesis recognizes that the informal sector is persistent and growing (ILO, 2018; Vanek et al., 2014). An extensive portion of self-employed in developing nations is busy in informal practices (Welter, Smallbone, \& Pobol, 2015). As a result, most of them moved into informal self-employed activities, including not registering their business, not paying taxes, and activities on cash in hand.

Entrepreneurship explains as a signal about recognizes and then explore an attractive and durable opportunity (Barringer \& Ireland, 2015). When Individuals explore an opportunity, they choose to start their start-up within formal or informal entrepreneurship. Nichter and Goldmark (2009) say that if entrepreneurs want to operate in a formal economy, they should follow the registration process and other institutions' regulations. Earning income from irregular and occasional activities refers to informal entrepreneurship. For example, entrepreneurs do not pay income or sales taxes, pay their friends or family members to provide help in their business, and do not pay social security benefits to their employees (Welter, Smallbone, \& Pobol, 2015). The informal entrepreneurs are defined in this research paper as "those starting a business or are the owner/manager of a business who engage in monetary transactions not declared to the state for tax, benefit and/or labour law purposes when they should be declared but which are legal in all other respect" (Williams \& Nadin, 2010).

Only goods/services being sold/bought (such as paid work) that are legitimate because of their non-declaration for tax or social security to the state or are not following the labour laws for benefits are included in the definition. If paid work is illegal (such as smuggling, drug trafficking), or unpaid work, or involves any unauthorized means of production and distribution is excluded from the definition of the informal economy for the aims of this study. This sphere holds blurred 
boundaries such as gifts at work. Moreover, prostitution is legal in some countries. Now, such increasing activities are treated separately from the informal economy; this economic sphere is known with the following labels "renegade" or "criminal" (see Williams, 2006; Webb et al., 2009). Informal entrepreneurship, in sum, is here defined as "involving somebody actively engaged in starting a business or is the owner/manager of a business who participates in the paid production and sale of goods and services that are legitimate in all respects besides the fact that they are unregistered by, or hidden from the state for tax and/or benefits purposes" (Williams, 2021).

Recent studies on informal entrepreneurship have ongoingly highlighted the difference between formal and informal practices. For example, those entrepreneurs who are working fully or partially informal can reduce their expenses by avoiding the social security contribution or avoiding taxation, or paying low salary than standard. Informal entrepreneurs increase their profit and income and take-home earnings (Welter, Smallbone, \& Pobol, 2015). They may earn extra earnings from the formal sector or establish for family or part-time informal entrepreneurial activities. At present, many studies on informal entrepreneurship have come to agree on its many-sided and complicated. Welter and Smallbone (2009) stated in their study that it is most suitable to think of various informality rather than trying to develop exclusive categories. In the last decade, informal entrepreneurship has achieved major significance in entrepreneurship and management research (e.g., Godfrey 2011; Siqueira, Webb, and Bruton 2014; Webb et al. 2013; Webb, Ireland, and Ketchen, 2014). Indeed, the literature of developing nations also provides striking evidence in the next section.

\section{Informal Entrepreneurship in Developing Countries}

The majority of academic researchers and economists have paid more attention to the formal sector than the informal, due to the nature of such enterprises is difficult to measure. However, in the 1970s, the "Informality" term was first used in developing economy Ghana by Keith Hart for petty entrepreneurs. In the early period, conventional scholars have constructed the formal and informal economy as a binary hierarchy; the informal economic sphere is treated as separate from the formal economy. It represents people engaged in the informal sector who marginalized from the formal economy (e.g., Castells \& Portes, 1989; Anwar, Akbar, Akbar, \& Azhar, 2017). In the conventional depiction, informality is represented as a declining sector and has negative attributes, such as low-paid exploitative and sweatshoplike work. After reviewing the literature of developing countries, it is concluded that workers tend to work at low wages, poor working conditions, long working hours with few benefits in the informal sector (e.g.). These studies have provided a strong view of resilient and 'marginality thesis'.

\section{The Policy and Practical Context of Informal Entrepreneurship}

Findings demonstrate that such activities are chiefly extraordinary in growing nations. A significant part of the Pakistani academic knowledge and literature covered in this research paper. To reduce or eliminate informal entrepreneurship, there are four main choices to consider: "take no action"; "pursue the eradication of informal entrepreneurship"; "move formal entrepreneurship into the informal economy"; or "transform informal entrepreneurship into formal entrepreneurship" (William, 2015). The first choice of "taking no action" is unacceptable for the state in the long-run policy approach. If the state takes no action against informal entrepreneurs, they engage in exploitative relationships with labour. The state revenue has been reduced if the state did not take action against those enterprises that did not pay full or partial taxes. Therefore, taking no action against informal entrepreneurship is not a reasonable choice (OECD, 2015). A second option is to shift formal to informal entrepreneurship. The objective of this option is to deregulate the formal sector might be no one engage in informal entrepreneurship. Still, the evidence showed that decreasing the intervention of the state leads the informal entrepreneurship. As a result, transitioning from the formal to the informal sector is impractical due to a lack of evidence that deregulation reduces informality.

The third option is to "eradicate informal entrepreneurship." When informal entrepreneurs are evading or hide taxes from the state to minimize their cost and increase their profitability (Richardson and Sawyer, 2001; Allingham and Sandmo, 1972; Grabiner, 2000). In this choice, the eradication of informality culture is followed by punishment for their bad practices and behavior. But it's debatable if this is, first and foremost, realistic and, second, attractive. On a practical level, the question is whether or not this is accurate.

While previous studies disclose that increasing detection practices and/or penalties decrease the informality culture and practices, others identify that informality increases (De Juan et al., 1994; Bergman and Nevarez, 2006; Slemerod et al., 2001; Murphy, 2005) and thus that "it is not sensible to penalize illicit work with intensified controls and higher fines" (Schneider and Enste, 2002). This is because a punitive approach alienates informal entrepreneurs, lowering their ability to comply and increasing informality by lowering their confidence in the system's fairness (Murphy, 2005).

Finally, converting informal entrepreneurship to formal entrepreneurship benefits governments by increasing public revenue and spending more on social security and integration programs. It also makes it easier to link the policy approach to informal entrepreneurship with the broader policy approach to entrepreneurship and business culture ( $\underline{\text { Small }}$ Business Council, 2004; Dekker et al., 2010).

Different EU governments, national agencies, and academic scholars have used the three approaches to eradicate or minimize informal entrepreneurship. These three approaches are divided into two categories that are direct control and indirect control. Direct control pursues to shift informal into formal entrepreneurship by confirming that the benefits are 
more significant in the formal economy than the informal economy. This is achieved by either "sticks" or "carrots". Indirect control does not use the "sticks" and "carrots" to minimize the hidden enterprise culture. But meanwhile, developing the relationship between state and informal entrepreneurs encourages formal entrepreneurship (European Commission, 2015). This study explains one by one.

\section{Deterrence Option: Direct Control (Sticks)}

Based on this derogatory portrayal of the informal economy, the only way to eliminate it is to ensure that the expected cost of getting caught and punished outweighs the economic gain of involvement. This is accomplished by rising identification rates and increasing penalties to alter the cost-benefit analysis (e.g., European Commission, 2015; Milliron and Toy, 1988). This approach to European Union nations usually has included sanctions, labour inspections, and organized state strategies.

For many years, this approach was adopted by most western governments (e.g., Hasseldineand Zhuhong, 1999) and supported by supra-national agencies (e.g., OECD, 2002) and many academic commentators (e.g., Sassen, 1989). Does this study see that is deterrence policy to eradicate or minimize informal entrepreneurship?

\section{Incentives: Direct Control (Carrots)}

The objective of this approach to encourage informal entrepreneurs to engage in formal entrepreneurship through providing incentives than eradication it (William, 2006). To minimize informal entrepreneurship. There are two forms of measures within this approach. The first measure provides incentives to informal entrepreneurs at the enterprise start-up phase to create their enterprises within the formal economy. Provides different benefits to entrepreneurs at the start-up stage, such as providing support services on how to set up their ventures formally or reduce direct or indirect taxes. The second measure provides incentives to those enterprises that are already established in the informal sector. In this measure, policymakers can take two forms of measures either supply-side or demand-side. Supply-side measure pursing informal entrepreneurs and provides different facilities such as voluntary disclosure plan/scheme, amnesties scheme, and facilitate the informal entrepreneurs to charming transition to formal entrepreneurship. Demand-side targeting the customers and offers incentives to those customers who used the formal enterprises than informal enterprises for any transaction. Service vouchers and tax incentives are examples of demand-side measures (European Commission, 2015; William, 2015).

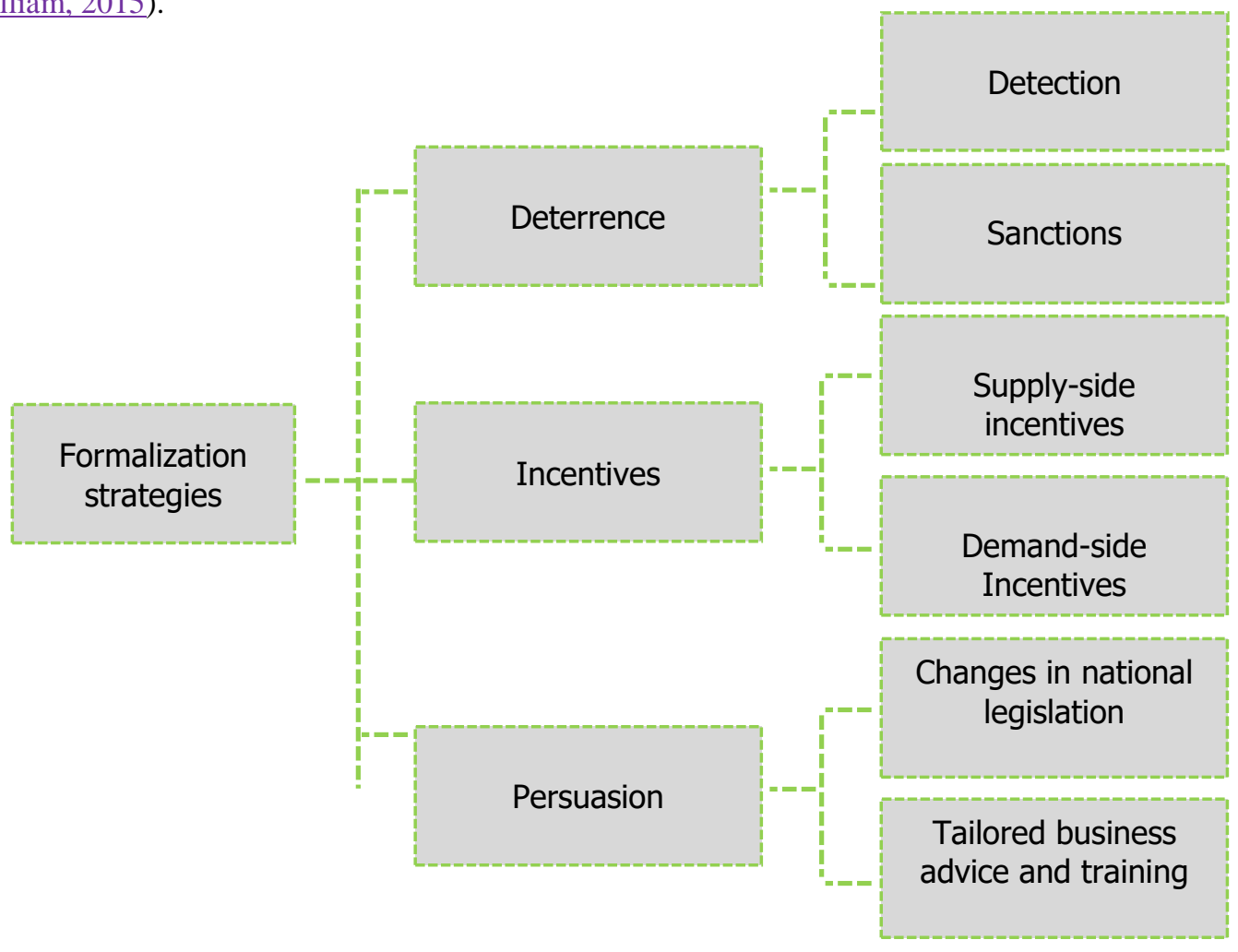

Figure 1: Formalization Strategies

Source: Williams (2015)

\section{Persuasion: Indirect Control (Reduce Asymmetry Between Informal and Formal Institutions)}

The direct approach focuses on "sticks" and "carrots," but the indirect approach focuses on improving the psychological relationship between entrepreneurs and government (European Commission, 2015; Torgler, 2007; Wenzel, 2002). This approach aims to produce voluntary promises to conforming behavior than force informal 
entrepreneurs to obey rules and regulations by using harassment, bribes, and/or threats (Torgler, 2011; Kirchler, 2007). Before using this approach, identify the different informal institutions' norms, values, and beliefs from formal institutions' codes and laws. To tackle the hidden enterprise culture is need to minimize the asymmetry between informal and formal institutions. This might be achieved by altering the formal and/or informal institution's values, norms, codes, and laws. This can be accomplished by increasing tax recognition through initiatives that educate people about the costs of informal entrepreneurship and the advantages of formal entrepreneurship and normative appeals.

In terms of formal institutions, two types of change are needed. Firstly, "there is often a need to change internal processes in the formal institutions to improve the perception amongst entrepreneurs that there is tax fairness, procedural justice, and redistributive justice" (Horodnic and Williams, 2019). Secondly, "there is often a need to change the products of formal institutions by pursuing wider economic and social developments" (Horodnic and Williams, 2019). Which policy approach(es) is(are) best to tackle informality culture in Pakistan?

\section{METHODOLOGY}

The interpretive tradition provided the philosophical assumptions that underpin this study. This suggests a subjective epistemology and an ontological belief in the social construction of truth. The epistemological stance on interpretive approaches is that facts of reality is expanded only over public constructions such as documents, tools, shared meanings, language, etc. (Walsham, 1993). Increased tax awareness can be achieved by programs that educate people about the costs of informal entrepreneurship and the benefits of formal entrepreneurship and normative appeals. Two types of changes are needed informal institutions (Kaplan and Maxwell, 1994). Indeed, the interpretive approach supports recognizing and understanding the respondents' perspectives, a reason to join this sector, and their opinions (case study constructed on the in-depth, open-ended questions in a semi-structured interview).

It has been challenging to measure the informal economy's magnitude and practices for academic researchers and policymakers. Many different methods have been used to study informal work; it entirely depends on available data banks and information. These methods can be classified into two core groups that are indirect and direct methods. Direct methods have been used to measure the size and nature of the informal economy. These are microeconomic methods that allow scholars to direct contact with participants working in the informal sector, and researchers pay attention to their stories. Versatility data have been collected from the horse's mouth via survey. This approach has high popularity in emerging and advanced nations because this method provides in-depth and accurate information. For data collection, the target population comprises micro and small firms from two sectors: retail and manufacturing. There is a deliberate exclusion of medium-sized enterprises on the grounds of the assumption that most of the start-ups in Pakistan, especially the ones in the informal economy, begin lifecycle on a micro or small scale. Unfortunately, there are no exact statistics available about small and micro-enterprises. The sample is covers enterprises in the sectors mentioned above located in the Gujranwala districts of Punjab. The unit of analysis is the individual. Respondents are informal entrepreneurs who are working in the Gujranwala district. Finally, a sample size of 30 has been used in this study. Fifteen respondents have been selected from each sector. Finally, this study has used 3 out of 6 sources of data collection. However, the prime source of data collection is the interview for this study because it allows one-to-one contact with participants (Denzin and Lincoln, 2008). Therefore, evaluate the thematic analysis is a better fit for this study and interpretive phenomenological analysis is unsuitable.

Holloway and Todres (2003) stated that thematic analysis is unclear, but some exponents have been replied to criticism mentioned above (e.g., Attride-Stirling, 2001). Braun and Clarke (2019) have been explained six key stages to conduct thematic analysis to overcome the criticisms. This thesis has been transferred thirty transcripts into qualitative software NVivo 10 when thirty interviews had been transcribed. Each interview was read systematically and thoroughly line by line and provided codes to each line and chunks. This is an ongoing process to creates limitless codes. Ethical procedures were considered during each phase of this study, especially the data collection stage. Make sure the 100 percent confidentiality of respondents. Real names were not used in this study; Pseudonyms were used instead of the real name.

\section{RESULTS}

\section{Participant's Demographic Profile}

The demographic overview based on respondent's education, their ages, and the nature of their business. All the participants interviewed were male and doing their business in different places of Gujranwala city. None of the thirty respondents was less than 30 years old. The researcher deliberately selected those participants for this study who were older than 30 years old because they have more experience of this market and know better about Gujranwala city and its market where they have been working. The majority of respondents are more than 40 years. Four participants were between 60-70, and three, between 51-60 years old. Almost 50 percent of respondents between 30-40 years old, and the rest of the participants fall between 41-50 years old (see table 1, at next page).

Table 1: Participant's Profile

\begin{tabular}{ccccccc}
\hline Pseudonym & Age & $\begin{array}{c}\text { Duration of } \\
\text { Interview }\end{array}$ & Nature of Business & $\begin{array}{c}\text { Business } \\
\text { Experience }\end{array}$ & Education & $\begin{array}{c}\text { Observations } \\
\text { During Interview }\end{array}$ \\
\hline
\end{tabular}




\begin{tabular}{|c|c|c|c|c|c|c|}
\hline Asif & 30 & 1.5 hours & $\begin{array}{l}\text { Manufacturing } \\
\text { Shopper making }\end{array}$ & 9 years & Primary & YES \\
\hline Ali & 37 & 2.5 hour & $\begin{array}{l}\text { Retailing } \\
\text { Male and female } \\
\text { undergarments }\end{array}$ & 20 years & Primary & YES \\
\hline Ashraf & 53 & 1.75 hour & $\begin{array}{l}\text { Retailing } \\
\text { Toys shop }\end{array}$ & 13 years & F.A & YES \\
\hline Basheer & & 2.25 hours & $\begin{array}{l}\text { Manufacturing } \\
\text { Steel kitchen pots }\end{array}$ & 35 years & Matric & YES \\
\hline Akram & 35 & 50 minutes & $\begin{array}{l}\text { Retailing } \\
\text { unstitch and stitch } \\
\text { garment }\end{array}$ & 40 years & Graduate & YES \\
\hline Majeed & 40 & 1.3 hour & $\begin{array}{l}\text { Manufacturing } \\
\text { disposable plastic cups } \\
\text { with lids }\end{array}$ & 40 years & Post Graduate & YES \\
\hline Arif & 45 & 1.5 hours & $\begin{array}{l}\text { Retailing } \\
\text { Decoration items }\end{array}$ & 30 years & LLB & YES \\
\hline Yasir & 38 & 2 hours & $\begin{array}{l}\text { Retailing } \\
\text { Women's garments }\end{array}$ & 42 years & Matric & YES \\
\hline Khurram & 65 & 1.7 hour & $\begin{array}{l}\text { Manufacturing } \\
\text { straw making }\end{array}$ & 5 years & F.A & YES \\
\hline Asif & 30 & 1.5 hours & $\begin{array}{l}\text { Manufacturing } \\
\text { Shopper making }\end{array}$ & 9 years & Primary & YES \\
\hline Umair & 37 & 2 hours & $\begin{array}{l}\text { Manufacturing } \\
\text { Straw making }\end{array}$ & 30 years & BBA LLB & YES \\
\hline Fiaz & 49 & 2.5 hour & $\begin{array}{l}\text { Manufacturing } \\
\text { Iron furniture }\end{array}$ & 42 years & Primary & YES \\
\hline Ahmad & 52 & 3 hours & $\begin{array}{l}\text { Manufacturing } \\
\text { Ice cream cone }\end{array}$ & 31 years & Matric & YES \\
\hline Hamza & 36 & 2.30 hours & $\begin{array}{l}\text { Manufacturing } \\
\text { Kitchen products }\end{array}$ & 18 years & F.A & YES \\
\hline Ajmal & 32 & 2.5 hour & $\begin{array}{l}\text { Retailing } \\
\text { Baby and toddler shop }\end{array}$ & 27 years & Post-Graduate & YES \\
\hline Shahzad & 51 & 1.5 hours & $\begin{array}{l}\text { Retailing } \\
\text { Plastic pots }\end{array}$ & 19 years & Matric & YES \\
\hline Raza & 65 & 3 hour & $\begin{array}{l}\text { Manufacturing } \\
\text { Disposable plastic plates }\end{array}$ & 14 years & Primary & YES \\
\hline Rehman & 40 & 2.5 hour & $\begin{array}{l}\text { Retailing } \\
\text { Kids garments }\end{array}$ & 31 years & B.A & YES \\
\hline Haider & 40 & 2 hour & $\begin{array}{l}\text { Retailing } \\
\text { Toys shop }\end{array}$ & 9 years & Matric & YES \\
\hline Iqbal & 45 & 55 minutes & $\begin{array}{l}\text { Manufacturing } \\
\text { Sports goods }\end{array}$ & 14 years & B.A & YES \\
\hline Nasir & 60 & 1.5 hours & $\begin{array}{l}\text { Retailing } \\
\text { Unstitch garments }\end{array}$ & 21 years & Post Graduate & YES \\
\hline Zafar & 50 & 3 hours & $\begin{array}{l}\text { Manufacturing } \\
\text { Packing box }\end{array}$ & 28 years & $\begin{array}{l}\text { Post Graduate } \\
\text { (M.com) }\end{array}$ & YES \\
\hline Fareed & 36 & 2.1 hours & $\begin{array}{l}\text { Retailing } \\
\text { Cosmetic products }\end{array}$ & 36 years & Matric & YES \\
\hline Naveed & 34 & 2.4 hour & $\begin{array}{l}\text { Manufacturing } \\
\text { Packed drinking water }\end{array}$ & 5 years & F.A & YES \\
\hline Tahir & 40 & 2.5 hours & $\begin{array}{l}\text { Retailing } \\
\text { readymade } \\
\text { garment } \\
\end{array}$ & 30 years & Graduate & YES \\
\hline Fraz & & 1.6 hour & $\begin{array}{l}\text { Manufacturing } \\
\text { Plastic kitchen pots }\end{array}$ & 42 years & Primary & YES \\
\hline Zunair & 45 & 2 hours & $\begin{array}{l}\text { Manufacturing } \\
\text { Cutlery products }\end{array}$ & 31 years & Matric & YES \\
\hline Tajammal & 37 & 1.30 hours & $\begin{array}{l}\text { Manufacturing } \\
\text { Shopper making }\end{array}$ & 18 years & F.A & YES \\
\hline
\end{tabular}




\begin{tabular}{ccclccc}
\hline Wahab & 47 & 1.6 hour & $\begin{array}{l}\text { Retailing } \\
\text { Plastic pots }\end{array}$ & 27 years & Primary & YES \\
\hline Sajid & 59 & 2.1 hours & $\begin{array}{l}\text { Manufacturing } \\
\text { French fries making }\end{array}$ & 12 years & B.A & YES \\
\hline Azeem & 60 & 1.4 hour & $\begin{array}{l}\text { Retailing } \\
\text { Garments }\end{array}$ & 20 years & Graduate & YES \\
\hline
\end{tabular}

Fifteen respondents were engaged in retailing businesses, and the rest of the respondents engaged in manufacturing business; detail is given in table 1 . There were only three participants who had less than three years of experience, the majority of respondents had 20 years of experience in those particular businesses. Table 1 shows that ten ( 33 percent) of the participants indicate that they had primary or less than primary education. 12 (40 percent) of the respondents proceeded to secondary education, and the rest of the respondents ( 27 percent) had graduation or higher formal education.

\section{Themes Identified for Policy}
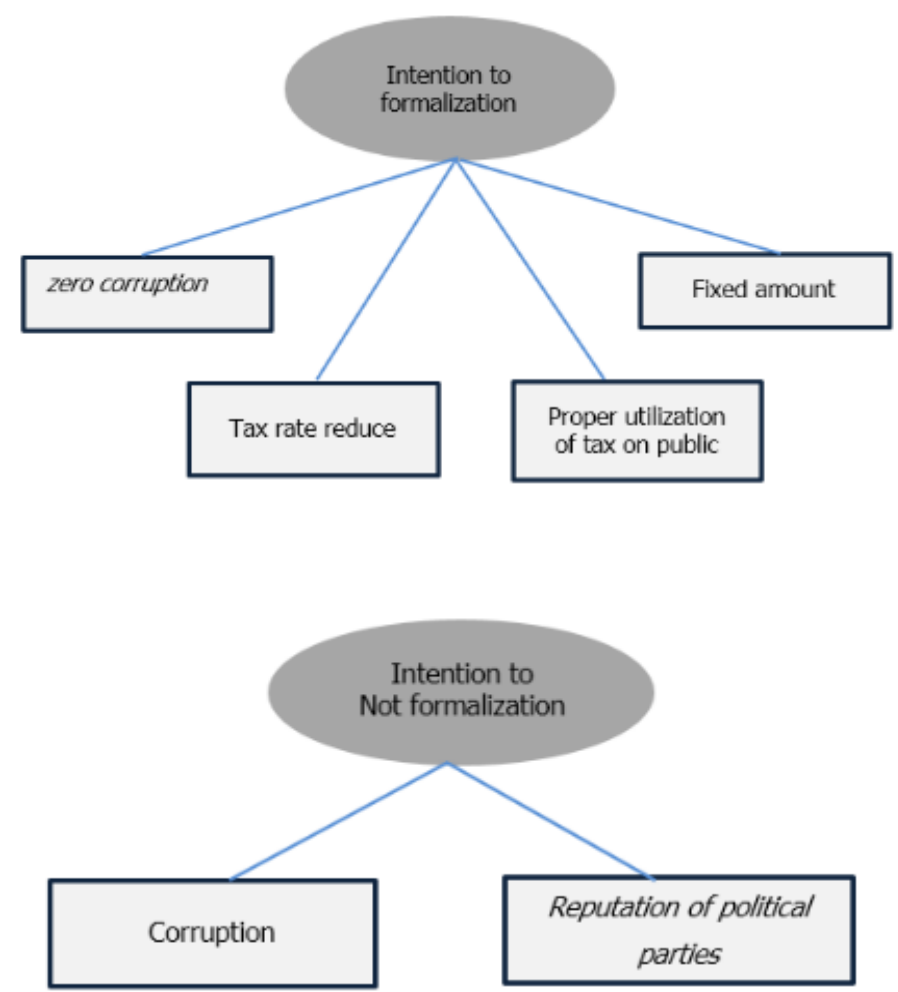

Figure 2: Thematic map of entrepreneur's response about the intention to formalization

\section{Theme 1: Intention to Formalization}

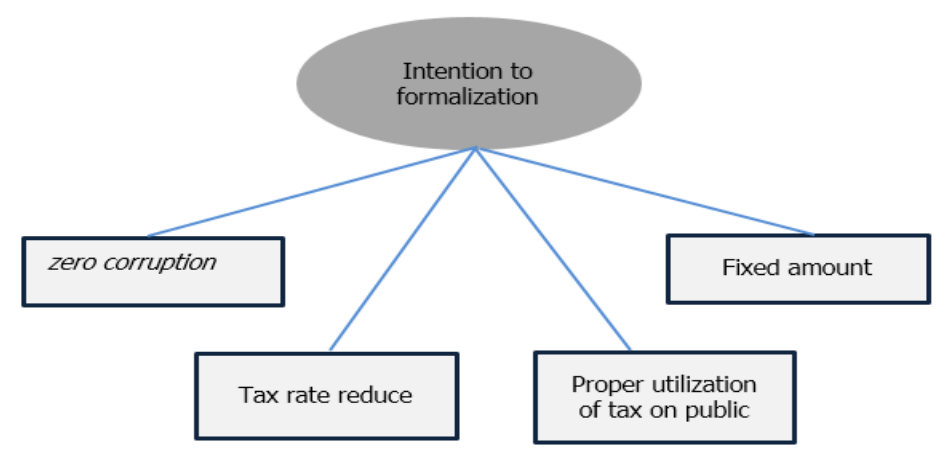

Figure 3: intention to formalization

\section{Subtheme 1: Zero Corruption}

Pakistani business communities want zero corruption of every government department. As expressed in the responses of participants. 
"In the current government, it's impossible for us to formalize if next government changes policies and tax collection plans, I will change my mind. A main and critical issue for me is the high rate of tax that should be minimized, and corruption in all state departments should also be abandoned. After all this, I am ready to register my business and pay all taxes” (Azeem, 60yrs, Retailing Kids garments)

“.....core topic for discussion in our country is corruption in every department” (Yasir, 38yrs, Women's garments)

"We are in a pool of corruption, and everyone thinks it's right to practice. I can understand it's not easy to change this system in a couple of years or in one decade, but we can minimize it from $90 \%$ to $40 \%$. If the government controls it in coming years, I will be ready to formalize my business" (Ahmad, 52yrs, Retailing Mobile accessories)

"Formalization is an adamant and strict set of rules and regulations that all followers have to follow. I am a small businessman unable to follow all procedures I am ready to formalize in case of any changes in regulations and standards" (Ali, 37yrs, Retailing in female and male undergarments)

"Corruption is the mother of all problems...it is the blood of our government department" (Ajmal, 32yrs, baby and toddler shop)

"State tries to eliminate or reduces the corruption from its institutions. You see every small enterprise must follow the rules and regulations" (Naveed, 34yrs, Packed drinking water)

\section{Subtheme 2: Tax Rate Reduces}

Informal entrepreneurs think that if the state reduces the tax rate, then we think about formalization. As expressed in the responses of participants.

"It is the responsibility of government they should decrease the rate of taxes. So, we need no to hide our profits. In case government makes policies, I will be ready to formalize” (Majeed, 40yrs, Manufacturing- disposable plastic cups with lids)

"My family is in this business for many years, and none of them pays tax everyone has the same reason that government should change policies and make in favor of businessmen like us so I do not pay my full tax. If government departments and their officials who prepare tax rules have some shame in them and they promise to give few advantages, then I will be the first to formalize in the market" (Naveed, 34yrs, Manufacturing-Packed drinking water)

“....Tax bracket is very high. I will pay, if the state reduces the tax bracket for small enterprises” (Akram, 35yrs, retailing of unstitching or stitch garments; similar views of Haider and Fiaz)

“.....profit margin is very low in our businesses, so the state needs to reduce the tax brace” (Zafar, 50yrs, Packing boxes)

\section{Subtheme 3: Proper Utilization of Tax on Public}

"Officials have fixed their rates for corruption and agreed to work in favor of businessmen. In our city, we have a shortage of resources which increase the burden of late production and delay in orders that's why we don't pay tax because we don't get any kind of benefit" (Rehman, 40yrs, Retailing of Kids garments)

“... taxes only for the politician, not for public” Naveed, 34yrs, (Manufacturing-Packed drinking water)

“...no direct benefits to general public...” (Zunair, 50yrs, Manufacturing-cutlery products)

If I saw any advantage, then I pay otherwise..." (Tahir, 40yrs, Retailing of readymade gents' garment)

\section{Subtheme 4: Fixed Amount}

On the other hand, tax rates are increasing with every passing year we won't make a profit. They have to make plans of three to four years to know our future tax rates.

\section{Theme 2: Intention to Not Formalization}

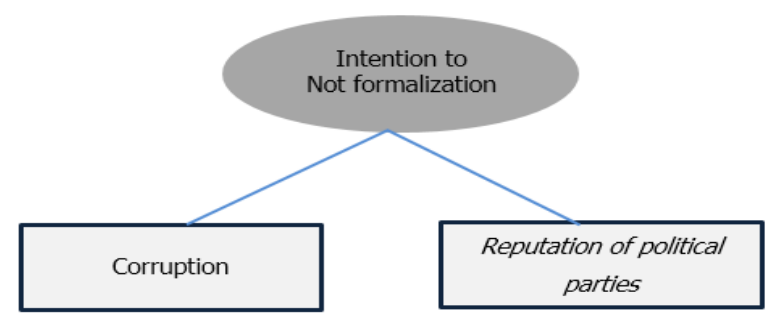

Figure 4: intentions to not formalization 


\section{Subtheme 1: Corruption}

Corruption is a curse not only for us but also for all of Pakistan's population, and it's a significant hurdle in the progress of all of us. No one is honest, especially government officials; that's why we also have to be involved in corruption activities and hide our actual income. In this state of corruption, I do not agree to formalize and suggest other business people the same (Sajid, 59yrs, Books, and stationery)

I know I am also a part of this system and engage in corruption activities. I have no other option left because we can't survive in such a system without this practice. So, I think it's easy to deal with officials by paying regular money as a gift that's why I don't need to be a part of tension by formalizing my business (Shahzad, 51yrs, Retailing of plastic pots)

My father is in this market scine1980 and knows all tactics and strategies of all government officials; he has formalized his business 18 years but unable to get any benefit in these years. So, he suggested not to formalize your business because it has no particular advantage for us (Raza, 65yrs, kitchen items)

\section{Subtheme 2: Reputation of Political Parties}

These days' government is facing many problems, and they are dealing with significant issues of the election, political instability, foreign pressure, and they have no concern with us. Their priorities for to collect tax, not to give any benefit to us. So, why I should formalize any single reason... (Hamza, 36yrs, Kitchen products)

For a small business, it's not easy to survive in the next few years and ups and downs are the parts of the business. I am new in the market and even I don't know where my business will stand in the future and have to change this line or not, then why should I formalize my business (Zunair, 50yrs, Manufacturing-cutlery products)

Prices of raw products or necessities are going higher and higher and due to tax rates and other family and business expenses, it's not favourable to formalize... (Khuram, 65yrs, Towel, and kitchen garments)

\section{DISCUSSION AND CONCLUSION}

\section{Best Policy to Tackle Informal Entrepreneurship}

Literature shows that there is no best policy option to tackle the hidden enterprise practices in Pakistan. In the literature section, evidence shows that three approaches have been used by different EU governments, national agencies, and academic scholars to eradicate or minimize informal entrepreneurship. These three approaches are divided into two categories that are direct control and indirect control. Direct control pursues to shift informal into formal entrepreneurship by confirming that the benefits are greater in the formal economy than the informal economy. This is achieved either by "sticks" or by "carrots." Indirect control does not use the "sticks" and "carrots" to minimize the hidden enterprise culture. Meanwhile, developing the relationship between state and informal entrepreneurs encourages formal entrepreneurship.

This study has explored determinants of informality before choosing the policy option. Bad policies, unreasonable and excessive regulations provide the opportunities to take bribes from concerning parties. Informal entrepreneurs are voluntarily chosen informal work due to the over-regulation and tight procedure for registration. In Pakistan, child labour is illegal, but during observation, this study finds that many child workers were working with very nominal salaries or daily wages in this hidden enterprise culture. This thesis also explored the majority of workers and entrepreneurs having no idea about social security. Policies and actions of the state may increase or fell the trust in the government. Hidden enterprise work practices also grow when the general public and businessmen evaporate the trust in government institutions and their political leaders. Transparency and accountability are creating a good image of the government in the business community. If the government does not do such things, the government loses its value. If the state fails to implement the policies honestly, transparently, efficiently, and accountable, this economy will also boost up. Responses of participants and observations of this study show that nobody is satisfied with government performance at the federal or provincial levels. They reply that everyone is corrupt and just thinks about its interest. As expressed by some Participants:

Now, these days government is facing many problems and is dealing with major issues of the election, political instability, and foreign pressure having the least concern with their priorities. They are not in favor of us, and they are not readily sharing benefits after tax collection. Therefore, I should not formalize for any single reason... (Hamza, 36yrs, Kitchen products)

Corruption is a curse not even for us; it's for all population of Pakistan, and it's a major hurdle in the progress of all of us. No one is honest, especially government officials and that's why we also have to be involved in corrupt activities and hide our real income. In this state of corruption, I do not agree to formalize and suggest other businessmen the same (Sajid, 59yrs, Books, and stationery)

Pakistani entrepreneurs are agreed that hidden enterprise culture should be eliminated, but they are not in favor of the deterrence policy approach. Because this approach is a "negative reinforcement" approach, it pursues the "sticks" to penalize bad behavior. Respondents expressed as: 
“...tough criteria may lead to more informality...” (Asif, Basheer, Naveed, Tajammal, Azeem, and Zafar have similar views)

"if the government uses sticks or threats which already do that...this strategy increases the proportion of informal economy” (Yasir, 38yrs, Retailing of Women's garments)

Therefore, participants agree with direct control policy options. Indirect control, policymakers can take two forms of measures, either supply-side or demand-side. Supply-side measures pursued informal entrepreneurs and provided different facilities such as voluntary disclosure plan/scheme, amnesty schemes, and informal entrepreneurs to charm the transition process to formal entrepreneurship. The demand-side approach targets the customers and offers incentives to those customers who use formal enterprises than informal enterprises for any transaction. Service vouchers and tax incentives are examples of demand-side measures (William, 2015). Participants of this study agree to use such incentives. Such facilities may encourage informal entrepreneurs to formalize their businesses rather than a deterrence approach.

The majority of participants agree with the indirect control policy approach. They express that relationship is more important than punishment or carrot. This approach aims to produce voluntary promises to conform behavior than force informal entrepreneurs to obey rules and regulations by using harassment, bribes, and/or threats (Torgler, 2011; Kirchler, 2007). Pakistani entrepreneurs also agree with Torgler and Kirchler's thoughts about the formalization of enterprises. Participants of this study demand that government should improve the tax knowledge using awareness campaigns. These awareness campaigns should cover the benefits of informal entrepreneurship and the cost/risks of informal entrepreneurship. This study has explored those participants who require some policy changes in state institutions. They demand that the state should deal with us respectfully, humbly, politely, courteously, impartially, unbiased, and responsible behavior. If the state practices such a manner, participants will show their willingness to pay 100 percent tax to fulfil their obligations honestly. State also uses the different normative appeal approaches to minimize the informality culture within Pakistan. The effectiveness and validity of appeals depend on how, when, and where the nature of appeals is made. In his study, Murphy (2005) stated that fair procedural treatment creates trust in entrepreneurs' official authorities. The participants also want fair procedural treatment.

\section{CONCLUSION}

This thesis has shown that either indirect or direct controls can be used. The various indirect control actions have been studied, along with the different direct control approaches that might be used. Finally, this study concludes that sectoral variations in the nature of informal work identified by various international studies (e.g., Williams, 2006; Williams and Windebank, 2006; Renooy et al. 2004; European Commission, 2007), one universal policy approach would not suit. The landscape of informal entrepreneurship is not homogenous in Pakistan. This study would have proposed that a crosssectoral comparison will be conducted in the future in Pakistan. This study has presented essential opportunities for future studies. The findings of this study are based on retail and manufacture-related respondents; researchers may collect data from different sectors. Furthermore, a countrywide survey can provide more accurate data on policy implications. In addition, researchers can explore the causes of lack of trust in the government and which barriers to face for policy implication.

\section{CONCLUSION}

The conclusion should be written in very clear words. It should explain how the objectives of the study are accomplished.

\section{ACKNOWLEDGEMENT}

We are thankful to all informal entrepreneurs who participated in this study.

\section{AUTHORS CONTRIBUTION}

Aamar Ilyas: [Principal investigator] Conceptualization; Design of work; NVivo software; Final draft preparation.

Muhammad Ali: Conceptualization; Methodology; Software; Analysis.

Ahmed Hussain Khan: Data collection; Writing.

Shahid Saleem: Review and Editing; Analysis.

Hafiz Muhammad Imran Akram: Proofreading of article.

\section{REFERENCES}

1. Allingham, M and A Sandmo (1972). Income tax evasion: a theoretical analysis. Journal of Public Economics, 1(2), 323-38. https://doi.org/10.1016/0047-2727(72)90010-2

2. Al-Mataani, R., Wainwright, T., \& Demirel, P. (2017). Hidden entrepreneurs: Informal practices within the formal economy. European Management Review, 14(4), 361-376. https://doi.org/10.1111/emre.12115 
3. Attride-Stirling, J. (2001). Thematic networks: an analytic tool for qualitative research. Qualitative research, 1(3), 385-405. https://doi.org/10.1177/146879410100100307

4. Barringer, B. R., \& Ireland, D. (2015). Entrepreneurship, Global Edition. Pearson Education Limited

5. Bennett, J. (2010). Informal firms in developing countries: entrepreneurial stepping stone or consolation prize?. Small Business Economics, 34(1), 53-63. https://doi.org/10.1007/s11187-009-9194-6

6. Bergman, M and A Nevarez (2006). Do audits enhance compliance? An empirical assessment of VAT enforcement. National Tax Journal, 59(4), 817-32. https://doi.org/10.17310/ntj.2006.4.04

7. Braun, V. \& Clarke, V. (2006) Using thematic analysis in psychology. Qualitative Research in Psychology, 3(2): 77-101. https://doi.org/10.1191/1478088706qp063oa

8. Braun, V., Clarke, V., Hayfield, N., \& Terry, G. (2019). Thematic analysis. Handbook of Research Methods in Health Social Sciences, 843-860. https://doi.org/10.1007/978-981-10-5251-4_103

9. Brown, D., \& McGranahan, G. (2016). The urban informal economy, local inclusion and achieving a global green transformation. Habitat international, 53, 97-105. https://doi.org/10.1016/j.habitatint.2015.11.002

10. Castells, M. and A. Portes (1989). World Underneath: The Origins, Dynamics, and Effects of the Informal Economy. A. Portes, M. Castells and L. A. Benton (eds), The Informal Economy: Studies in Advanced and Less Advanced Developed Countries. Baltimore: Johns Hopkins University Press.

11. De Juan, A, MA Lasheras and R Mayo (1994). Voluntary tax compliant behavior of Spanish income taxpayers. Public Finance, 49, 90-105.

12. Dekker, H., Oranje, E., Renooy, P., Rosing, F and Williams, C.C. (2010). Joining up the Fight against Undeclared Work in the European Union. Brussels: DG Employment, Social Affairs and Equal Opportunities.

13. Denzin, N. K., \& Lincoln, Y. S. (2008). Strategies of qualitative inquiry (Vol. 2). Sage.

14. European Commission (2007). Stepping up the Fight against Undeclared Work. Brussels: European Commission.

15. European Commission (2015). Policy brief on informal entrepreneurship. Brussels: European Commission

16. Godfrey, P. C. (2011). Toward a theory of the informal economy. The Academy of Management Annals, 5(1), 231-277. https://doi.org/10.5465/19416520.2011.585818

17. Grabiner Lord (2000). The Informal Economy. London: HM Treasury.

18. Günther, I., \& Launov, A. (2012). Informal employment in developing countries: Opportunity or last resort?. Journal of development economics, 97(1), 88-98. https://doi.org/10.1016/j.jdeveco.2011.01.001

19. Hasseldine, J. and Li, Z. (1999). More tax evasion research required in new millennium. Crime, Law and Social Change, 31(1), 91-104. https://doi.org/10.1023/A:1008324726125

20. Holloway, I. \& Todres, L. (2003) The status of method: flexibility, consistency and coherence. Qualitative Research, 3: 345-357. https://doi.org/10.1177/1468794103033004

21. Horodnic, I.A. and Williams, C.C. (2019), "Evaluating policy approaches for tackling informal entrepreneurship", Journal of Small Business and Enterprise Development, 26(4), 595-611. https://doi.org/10. 1108/JSBED-08-2018-0252

22. ILO. (2018). Women and men in the informal economy: A statistical picture. Geneva: International Labor Office.

23. Ilyas, A., Shahid, M.S. and Ali Hassan, R. (2020). Evaluating the motives of child labourers in the informal economy. International Journal of Sociology and Social Policy, Vol. 40 No. 3/4, pp. 40924. https://doi.org/10.1108/IJSSP-01-2019-0001

24. Kaplan, B., \& Maxwell, J. A. (1994). Evaluating health care information systems: Methods and applications. Qualitative Research Methods for Evaluating Computer Information Systems. JG Anderson, CE Ayden and SJ Jay. Thousand Oaks, Sage.

25. Kirchler, E. (2007). The Economic Psychology of Tax Behaviour. Cambridge: Cambridge University Press. https://doi.org/10.1017/CBO9780511628238

26. Mughal, K., \& Schneider, F. (2018). Shadow Economy in Pakistan: Its Size and Interaction with Official Economy.

27. Murphy, K (2005). Regulating more effectively: the relationship between procedural justice, legitimacy and tax non-compliance. Journal of Law and Society, 32(4), 562-89. https://doi.org/10.1111/j.1467-6478.2005.00338.x

28. Neuwirth, R. (2011). Stealth of nations: The global rise of the informal economy. NewYork: Random House

29. Nichter, S., \& Goldmark, L. (2009). Small firm growth in developing countries. World development, 37(9), 1453-1464. https://doi.org/10.1016/j.worlddev.2009.01.013

30. OECD (2004). Reducing the Risk of Policy Failure: Challenges for Regulatory Compliance. Paris: OECD.

31. Renooy, P, S Ivarsson, O van der Wusten-Gritsai and R Meijer (2004). Undeclared Work in an Enlarged Union: an analysis of shadow work - an in-depth study of specific items. Brussels: European Commission.

32. Richardson, $\mathrm{M}$ and A Sawyer (2001). A taxonomy of the $\mathrm{t}$ ax compliance literature: further findings, problems and prospects. Australian Tax Forum, 16(2), 137-320

33. Schneider, F., \& Enste, D. H. (2002). The Shadow Economy: Theoretical Approaches, Empirical Studies, and Policy Implications.

34. Siqueira, A. C. O., Webb, J. W., \& Bruton, G. D. (2016). Informal entrepreneurship and industry conditions. Entrepreneurship Theory and Practice, 40(1), 177-200. https://doi.org/10.1111/etap.12115 
35. Small Business Council (2004). Small Business in the Informal Economy: making the transition to the formal economy. London: Small Business Council.

36. Suhaimi, N. H. B. M., Al Mamun, A., Zainol, N. R., Nawi, N. C., Permerupan, Y., \& Malarvizhi, C. A. (2016). Characteristics of Informal Micro-Entrepreneurs in Malaysia. Mediterranean Journal of Social Sciences, 7(2), 128.

37. Thai, M. \& Turkina, E. (2013). Entrepreneurship in the Informal Economy: Models, Approaches and Prospects for Economic Development. New York: Routledge

38. Torgler, B (2007). Tax morale in Central and Eastern European countries. In Tax Evasion, Trust and State Capacities: how good is tax morale in Central and Eastern Europe?, N Hayoz and S Hug (eds.), pp.155-86. Bern: Peter Lang.

39. Torgler, B (2011). Tax Morale and Compliance: review of evidence and case studies for Europe. Washington DC: World Bank Policy Research Working Paper 5922, World Bank. https://doi.org/10.1596/1813-9450-5922

40. Vanek, J., Chen, M. A., Carré, F., Heintz, J., \& Hussmanns, R. (2014). Statistics on the informal economy: Definitions, regional estimates and challenges. Women in Informal Employment: Globalizing and Organizing (WIEGO) Working Paper (Statistics), 2.

41. Walsham, G. (1993). Interpreting information systems in organizations. John Wiley \& Sons, Inc.

42. Webb, J. W., Bruton, G. D., Tihanyi, L., \& Ireland, R. D. (2013). Research on entrepreneurship in the informal economy: Framing a research agenda. Journal of Business Venturing, 28(5), 598-614. https://doi.org/10.10 16/j.jbusvent.2012.05.003

43. Webb, J. W., Ireland, R. D., \& Ketchen Jr, D. J. (2014). Toward a greater understanding of entrepreneurship and strategy in the informal economy. Strategic Entrepreneurship Journal, 8(1), 1-15. https://doi.org/1 $0.1002 /$ sej. 1176

44. Webb, J. W., Tihanyi, L., Ireland, R. D., \& Sirmon, D. G. (2009). You say illegal, I say legitimate: Entrepreneurship in the informal economy. Academy of Management Review, 34(3), 492-510. https://doi.or g/10.5465/amr.2009.40632826

45. Welter, F., Smallbone, D., \& Pobol, A. (2015). Entrepreneurial activity in the informal economy: a missing piece of the entrepreneurship jigsaw puzzle. Entrepreneurship \& Regional Development, 27(5-6), 292-306. https://doi.org/10.1080/08985626.2015.1041259

46. Wenzel, M. (2002). The impact of outcome orientation and justice concerns on tax compliance: the role of taxpayers' identity, Journal of Applied Psychology, 87: 639-45.

47. Williams, C. C. (2021). Evaluating entrepreneurs'motives for participating in the informal sector in europe. Journal of Developmental Entrepreneurship. https://doi.org/10.1142/S1084946721500023

48. Williams, C. (2014). Informal sector entrepreneurship. OECD.

49. Williams, C. C. (2015). Tackling entrepreneurship in the informal sector: An overview of the policy options, approaches and measures. Journal of Developmental Entrepreneurship,20(01). https://doi.org/10.1142/ S1084946715500065

50. Williams, C. C., \& Nadin, S. (2010). Entrepreneurship and the informal economy: An overview. Journal of Developmental Entrepreneurship, 15(04), 361-378. https://doi.org/10.1142/S1084946710001683

51. Williams, C. C., \& Schneider, F. (2016). Measuring the Global Shadow Economy: the prevalence of informal work and labour. Edward Elgar Publishing.

52. Williams, CC (2006). The Hidden Enterprise Culture: entrepreneurship in the underground economy. Cheltenham: Edward Elgar. https://doi.org/10.4337/9781847201881

53. Williams, CC and J Windebank (1998). Informal Employment in the Advanced Economies: implications for work and welfare. London: Routledge.

54. Williams, CC and J Windebank (2006). Harnessing the hidden enterprise culture of advanced economies. International Journal of Manpower, 27(6), 535-551. https://doi.org/10.1108/01437720610690473

55. Williams, C. C., and J. Round. (2009). Evaluating informal Entrepreneurs' Motives: Some Lessons from Moscow. International Journal of Entrepreneurial Behaviour and Research, 15(1), 94-107 https://doi.org/ $\underline{10.1108 / 13552550910934477}$

56. Xheneti, Mirela, David Smallbone, and Friederike Welter. 2013. EU Enlargement Effects on CrossBorder. 